\title{
微細結晶粒材の曲げ加エにおける結晶方位データベースの構築
}

\section{Construction of database for grained materials with bending}

$\bigcirc$ 学 平尾 哲朗(高松高専・専)

Tetsuro HIRAO, Takamatsu National College of Technology

正 橋本 良夫(高松高専)

Yosio HASIMOTO, Takamatsu National

College of Technology
正 酒井 孝(成蹊大学)

Takashi SAKAI, Seikei University

Key Words: Bending property, Spring back, Fine crystal grain, SEM-EBSD analysis

\section{1 緒言}

金属材料を合金化せずに強ひずみ加工を施すことで，リサ イクル性や強度，耐食性に優れた「スーパーメタル」を創製 することができる。これを広範囲な産業分野八応用すること でさらなる軽量化が実現化され，燃費向上による省エネルギ 一化や二酸化炭素放出量の低減に寄与することができる.さ らにこのスーパーメタルは, 微細化を促進する合金元素を添 加することなく Hall-Petch 則に従い高強度化が実現できるた め製品廃棄後のリサイクル性が良く, 資源問題に大きく貢献 できる，また，高強度だけでなく高延性も実現するため，塑 性加工に扝ける被加工材として大きな可能性をもっている と考えられる。しかしながら，その加工特性は依然として不 明であり，市場に流通する前に十分な加工特性を把握する必 要がある。

本研究では微細結晶粒材の加工特性を把握するために, 塑 性加工に伴う結晶方位データをデータベースにまとめて統 計的に処理を行い, 塑性加工に有用なデータを調査した。こ れらを明らかにすれば，加工特性を制御して結晶粒微細化材 の高精度塑性加工を実現できるだけでなく, 新たな塑性加工 方法の提案に応用できると考えられている.

\section{2 これまでに得られた成果とデータベース構築へのつながり}

これまでに各種鉄鋼材料(SUS,SPCC,SS の各材)に対して ARB(連続強圧延)法による結晶粒微細化を行い, NFG 鋼(熱 間強圧延材) と併せて引張試験や各種機械的性質や曲げ試験 によるスプリングバック特性について調べてきた．また，有 限解析ソフト AITAS により解析的にこれらの結晶粒微細化 材のスプリングバック量を予測した。これらの研究より，下 記の結果を得た。

1 つ目に, ス一パーメタルの塑性加工特性は, 従来材料の ものと大きく異なることが明らかになった．また，これに関 して, 曲げ加工によるスプリングバック特性も大きく異なる ことが明らかになった.さらに, 結晶粒微細化材のスプリン グバック量は, 材料定数やその他の微視的な特異因子の影響 で，有限解析ソフト AITAS では十分な予測ができないこと がわかった。

2つ目に，スーパーメタルの塑性加工技術を確立するため には, 塑性加工にともなう結晶方位データをまとめて統計的
に処理する必要があることがわかった．微細結晶粒材の曲げ 加工特性を正確に把握するためには，微細結晶粒材の特異な 加工特性を支配する微視的要因を明らかにすることが急務 でありこれまでに試験的に結晶学的な観点から結晶回転, 集合組織，大・小角粒界，その他の影響に着眼して曲げ部の 結晶方位観察を行ってきた。これまでの定量データが，曲げ 部の SEM-EBSD 観察から得られた. 統計的処理を行うため に,さらなるデータの補充が必要であると考えられる.

\section{3 解析方法とデータベースの構築手順}

\section{1 解析方法}

結晶粒の観察方法として SEM-EBSD 解析を用いた。曲げ 試験を行った試料において Fig.1 に示す ND 面の 3 点の SEM-EBSDによる方位観察を行った。

解析面を機械式による 800 番のエメリーペーパー, ダイヤ モンド，コロイド研磨の順で仕上げたあとに SEM 装置の真 空チャンバー内にセットした。 チャンバー内を真空にして SEM 画像を観察し, 解析点を定め, EBSD カメラを真空チャ ンバ一内に挿入し, 㐘池線を確認して解析を開始した。

SEM-EBSD 解析により得たオイラー角デー夕を, 方位集計 プログラムにより ND面の方位分布を算出した。この自作し たアプリケーションの画面の様子を Fig.2 に示す.この特徵 として, 視覚的にわかりやすく逆極点図を表示するとともに, 右下にND面の結晶方位の割合が表示されるように工夫した。 Fig.2の左上の大角粒界, 小角粒界はオイラー角のデータか ら方位を求め, 周りの隣接方位から方位差を求めた。 そして 方位の角度差を算出し， $\theta>15^{\circ}$ を大角粒界 $5^{\circ}<\theta<1^{\circ}$ を小 角粒界と定義した. 大角粒界が減少し小角粒界が増加するこ とは, 強圧延により動的再結晶に起因する再結晶粒の形成が 進んでいることを表している.

Fig.3 は, Fig.2 に示したアプリケーションから得られたデ 一タを, データベースに人力するインターフェイスである.

結晶方位の分割に関しては, Fig.4 に示すように逆極点㘠 を半径方向, $\theta$ 方向それぞれ 10 分割する作業を行った. Fig.4 の斜線を引いている範囲に集まっている方位を，それぞれ[0 $\left.\begin{array}{ll}0 & 1\end{array}\right],\left[\begin{array}{lll}1 & 0 & 1\end{array}\right],\left[\begin{array}{lll}1 & 1 & 1\end{array}\right]$ の方位の分布と定義して Fig.2の方位集 計計算を行った。この作業は, 将来的にさらに方位分布を細 分化するときに有用となる. 


\section{2 データの応用}

Fig.3 に実験データの入力インターフェイスを示したが, このプログラム作成と同時に，Figs.5,6 のような出力プログ ラムも作成した。これは任意の結晶方位の割合を入力するこ とで，それに対応したスプリングバック量を定量的に推定す ることができるものである.これと逆にスプリングバック量 を制御したい場合，一義的ではないものの，そのスプリング バック量を実現できる材料の結晶方位の割合について出力 することができる.



Fig.1 Analytical points of SEM-EBSD analysis.

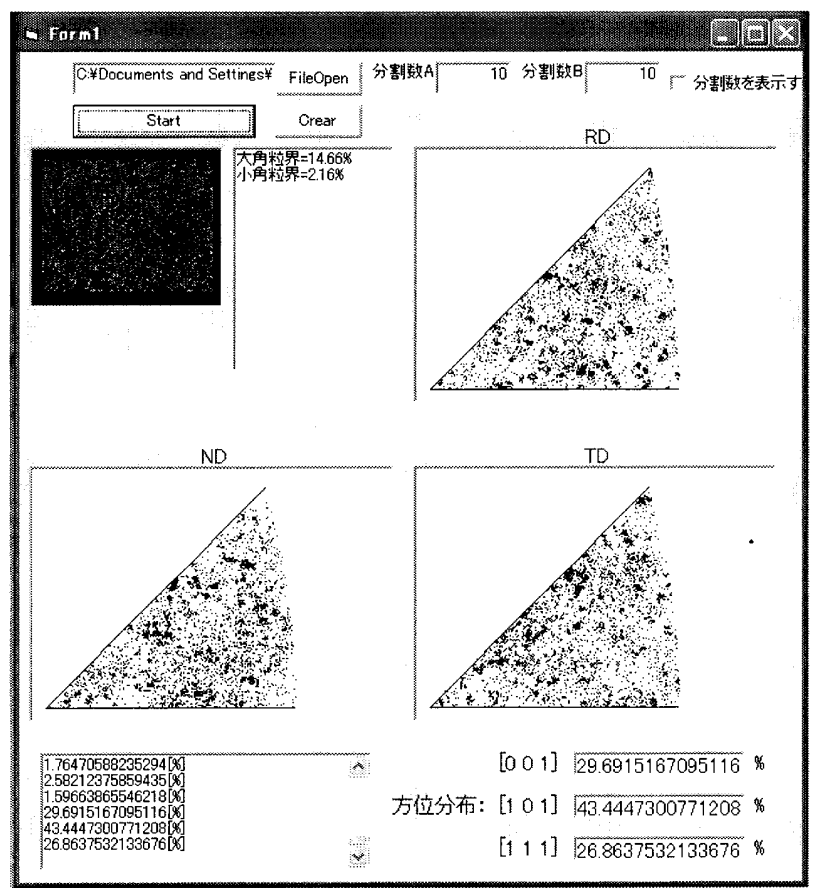

Fig.2 Viewing image of analytical software.

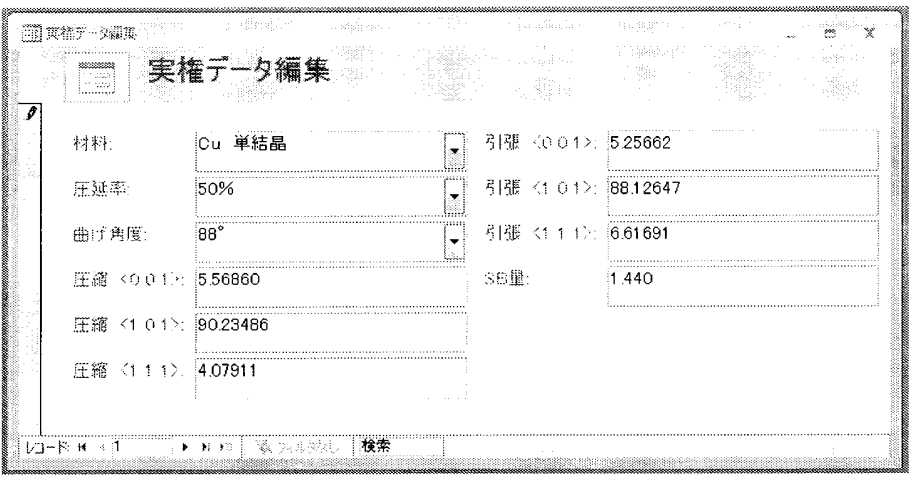

Fig.3 User interface of proposed data base.
このようなデータベースの構築により，微細結晶粒材の高 精度塑性加工を実現できることになる。また，このデータべ 一スの幅広い援用が，従来金属の新しい塑性加工方法にも応 用できると考えている.

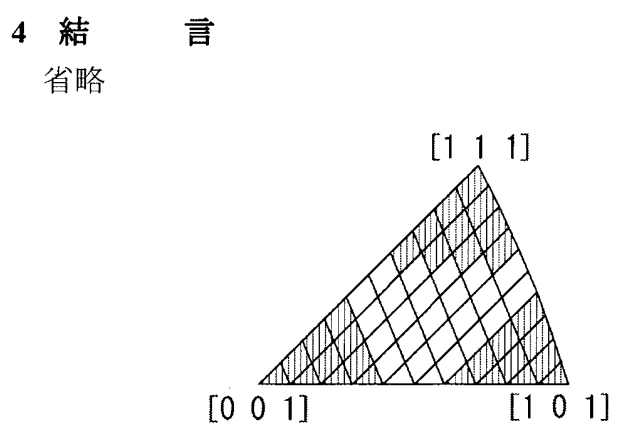

Fig.4 Definition of orientation distribution.

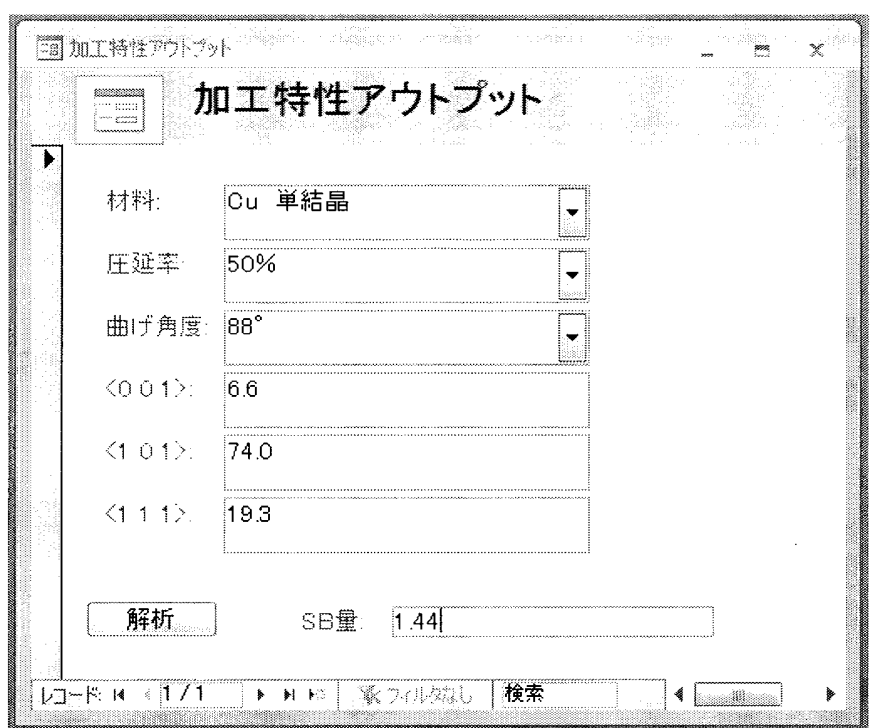

Fig. 5 User interface of proposed software;

1. output of spring back degree

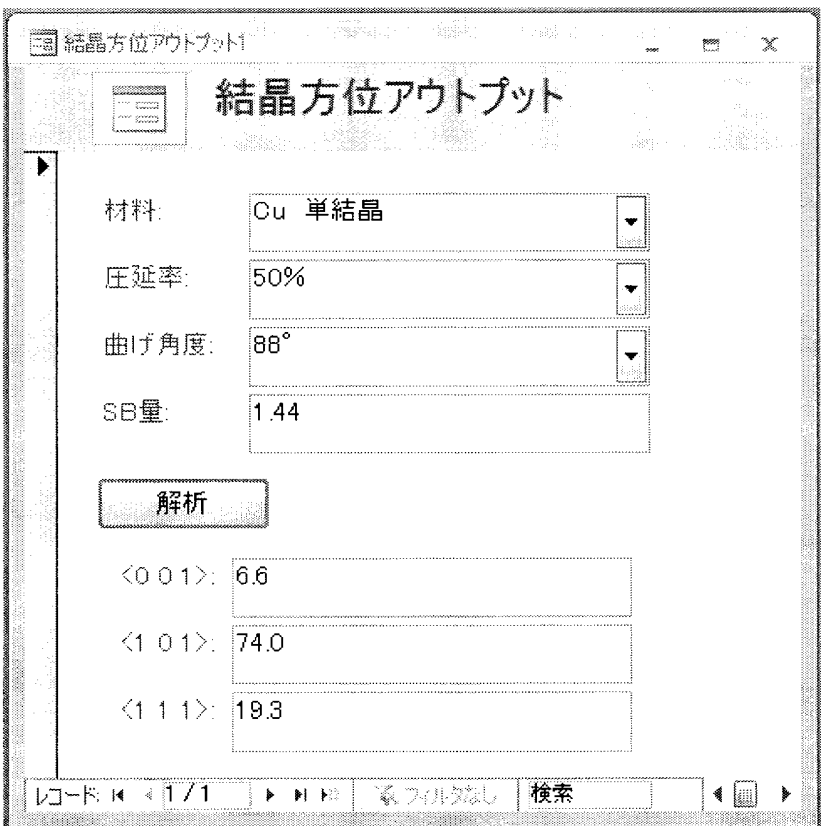

Fig.6 User interface of proposed software;

2. output of orientation ratio 